doi: $10.2306 /$ scienceasia1513-1874.2014.40.327

\title{
Immobilization of a thermophilic solvent-stable lipase from Acinetobacter baylyi and its potential for use in biodiesel production
}

\author{
Pakorn Winayanuwattikun $^{\mathrm{a}}$, Kingkaew Piriyakananon ${ }^{\mathrm{a}}$, Phenwarat Wongsathonkittikun ${ }^{\mathrm{b}}$, \\ Jittima Charoenpanich ${ }^{\mathrm{b}, \mathrm{c}, \mathrm{d}, *}$ \\ a Department of Biochemistry, Faculty of Science, Chulalongkorn University, Bangkok 10330 Thailand \\ b Department of Biochemistry and Centre of Excellence for Innovation in Chemistry (PERCH-CIC), \\ Faculty of Science, Burapha University, Bangsaen, Chonburi 20131 Thailand \\ c Environmental Science Program, Faculty of Science, Burapha University, Bangsaen, \\ Chonburi 20131 Thailand \\ d Centre of Excellence on Environmental Health and Toxicology (CHE), Ministry of Education, Thailand \\ *Corresponding author, e-mail: jittima@buu.ac.th
}

Received 3 Jan 2014

Accepted 16 Sep 2014

\begin{abstract}
Lipase transesterification of triglycerides is an environmentally safe alternative to chemical processing during biodiesel production. However, the cost and low stability of this enzyme remains problematic for commercial production. In this study, a thermophilic-solvent stable lipase from Acinetobacter baylyi (ABL) immobilized on Sepabeads EC-OD showed improved solvent stability. The optimal reaction conditions of immobilized ABL were comparable with those of the suspended lipase. Immobilization of $\mathrm{ABL}$ resulted in a broader $\mathrm{pH}$ activity range and enhanced storage stability. Optimal conditions for transesterification of palm oil were 6-step methanol feeding, 1:4 oil/methanol molar ratios, 20\% enzyme loading, and $4 \%$ water content for $24 \mathrm{~h}$ at $40{ }^{\circ} \mathrm{C}$. Conversions of oil feedstocks to biodiesel of between 13 and 93\% were obtained. Reusability for transesterification of immobilized ABL was comparable to that of commercial lipases. This study found that immobilized ABL is one of the biocatalyst candidates for further development and application in enzyme-catalysed biodiesel synthesis.
\end{abstract}

KEYWORDS: physical adsorption, solvent stability, thermostability, transesterification

\section{INTRODUCTION}

Biodiesel is becoming an increasingly important alternative fuel due to its domestic production thereby reducing petroleum imports and harm to the environment ${ }^{1,2}$. Several biodiesel production processes have been developed, among which lipase transesterification of triglycerides has become particularly attractive $^{3,4}$. However, the main impediment to commercialize this process is the high cost and low stability of the lipase. In addition, inactivation of lipases by methanol hampers further applicability of enzymatic transesterification. Most attempts to overcome these problems use commercial immobilized lipases ${ }^{5-8}$ but the enzyme cost preclude industrial implementation.

Acinetobacter baylyi lipase (ABL) is a novel thermophilic and solvent-stable enzyme capable of catalysing the transesterification of palm oil to fatty acid methyl esters ${ }^{9}$. Acinetobacter are well represented among fermenting bacteria to produce a number of extra- and intracellular economic products, including lipases ${ }^{10,11}$. Biotechnological contributions by Acinetobacter seem to mirror those of Pseudomonas sp. in vigour and versatility. The genome of Acinetobacter however contains few traits that might be associated with pathogenesis in contrast to Pseudomonas ${ }^{11}$. Most lipases produced by Acinetobacter sp. have biochemical properties similar to those produced by Pseudomonas sp. and Burkholderia $\mathrm{sp}$., including stability and maximum activity under alkaline conditions at high temperature ${ }^{10,12}$. A suspended form of the enzyme usually exhibits lower stability and greater resistance to enzyme recovery and re-use, restricting its practicality ${ }^{13}$. Immobilized enzymes may overcome many of these issues within industrial applications, as they can lead to enhanced enzyme stability, activity and recovery, and ultimately to a significant production economic benefits ${ }^{14}$. In this study, ABL was immobilized onto commercial hydrophobic supports by simple adsorption. Lipolytic 
activity and stability of the immobilized lipase were investigated in comparison to reported values for the suspended $\mathrm{ABL}^{9}$ and commercial lipases. Finally, the transesterification of oils in methanol by immobilized ABL was assessed.

\section{MATERIALS AND METHODS}

\section{Materials}

Non-edible oils (cotton, papaya, physic nut, pomelo, pumpkin, rambutan, and rubber) were extracted from seeds ${ }^{15}$. Edible oils such as canola, coconut, corn, olive, palm, rice bran, safflower, sesame, soya bean, and sunflower were purchased in a supermarket. Commercial polymer supports (Amberlite XAD7HP, Amberlite XAD761, Amberlite XAD16, and Sepabeads EC-OD) were purchased from Rohm \& Haas Co., Ltd. (USA) and Resindion Srl (Mitsubishi Chemical Corporation, Milan, Italy). Commercial immobilized lipase from Rhizomucor miehei (Lipozyme RM IM) was bought from Novo Nordisk (Denmark). The enzyme is immobilized on macroporous anionic resin beads (Duolite A568) (approximately 14\% proteins are adsorbed onto the resin $\mathrm{g} / \mathrm{g}$ ). The yeast, Candida antartica lipase $\mathrm{B}$ immobilized on macroporous acrylic resin (Novozyme 435) was purchased from Sigma-Aldrich (Tokyo) and classified as belonging to the triacylglycerol hydrolases (EC 3.1.3.3), with a declared activity of $\geqslant 10000 \mathrm{U} / \mathrm{g}$ (propyl laurate units per gram). All other chemicals were purchased from Sigma and were of analytical grade.

\section{Bacterial strain and culture condition}

The bacterial strain used in this study, A. baylyi, was isolated from marine sludge in Thailand ${ }^{9}$. Lipase was produced in 1-1 of 5-fold dilution of Luria-Bertani medium ${ }^{16}$ containing $0.8 \%(\mathrm{v} / \mathrm{v})$ of tween 80 as an inducer ${ }^{17}$ at $25^{\circ} \mathrm{C}$ and $150 \mathrm{rpm}$ for $15 \mathrm{~h}$. When cell growth reached the late exponential phase, the culture broth was centrifuged for $20 \mathrm{~min}$ at $4{ }^{\circ} \mathrm{C}, 10000 \mathrm{~g}$. The supernatant containing extracellular lipase was filtered through a $0.2 \mu \mathrm{m}$ nylon membrane filter and harvested for lipase assay. Purification was performed as previously described ${ }^{9}$.

\section{Lipase activity assay and protein determination}

Hydrolytic activities of suspended and immobilized lipase were related to spectrophotometric absorption $(410 \mathrm{~nm})$ promoted by the hydrolysis of $p$-nitrophenol ${ }^{18}(p$-NPP). One unit (U) of enzyme was defined as the amount of enzyme releasing $1 \mu \mathrm{mol}$ of $p$-NP per minute under assay conditions. Amount of $p$-NP was calculated from a standard curve. In addition, hydrolysis of palm oil was determined as described previously using $50 \mathrm{mM} \mathrm{NaOH}$ and phenolphthalein as titrant and indicator, respectively ${ }^{19}$. One unit of lipase activity was defined as the amount of enzyme associated with the release of $1 \mu \mathrm{mol}$ of free fatty acid per minute under test condition. Enzyme activity of immobilized lipase is expressed as enzyme units/g of polymer support.

In transesterification, the stepwise methanolysis of palm oil was conducted as follows: $1 \mathrm{~g}$ of palm oil was added to lipase and later mixed with 1:3 mole ratio of methanol ${ }^{20}$. Reactions were carried out by stirring the mixtures for $24 \mathrm{~h}$ at $40^{\circ} \mathrm{C}$. Samples were taken from the reaction mixture and further analysed for the products by high performance liquid chromatography ${ }^{15}$. Conversion of the transesterification reaction was equated to the ratio of fatty acid methyl esters and glycerides produced in the reaction.

Total protein concentration was determined spectrophotometrically according to Bradford ${ }^{21}$ using Bio-Rad assay reagent (Hercules, USA). The protein standard was bovine serum albumin. Lipase loading efficiency was defined as the percentage of enzymes on the supporter based on protein concentration before and after immobilization.

\section{Preparation of immobilized lipase from A. baylyi}

Hydrophobic supports $(1 \mathrm{~g})$ were washed with $3 \mathrm{ml}$ of methanol and stirred (350 rpm) for $30 \mathrm{~min}$ at room temperature. Methanol was removed by filtration and the supports were washed 3 times with an equal volume of $20 \mathrm{mM}$ phosphate buffer $(\mathrm{pH} 7.5)$ for $30 \mathrm{~min}$. The supports were dried at $45^{\circ} \mathrm{C}$ for $12 \mathrm{~h}$. A specified amount of support $(1 \mathrm{~g})$ was suspended in $500 \mathrm{ml}$ of ABL solution $(3 \mathrm{mg} / \mathrm{ml})$ prepared in $20 \mathrm{mM}$ phosphate buffer $(\mathrm{pH} 7.5)$ and stirred $(350 \mathrm{rpm})$ for $6 \mathrm{~h}$ at room temperature. Immobilized supports were separated by filtration and washed thoroughly with $20 \mathrm{mM}$ phosphate buffer (pH 7.5) and distilled water (100 ml each). Supernatants and washings were assayed for lipase activity and protein content. Protein bound on supports was calculated as the difference between that loaded and suspended in supernatants and washings. Immobilized supports designated as immobilized ABL were dried in a desiccator at room temperature and finally activities were assayed from hydrolysis and transesterification of palm oil. During immobilization, parameters were optimized: $\mathrm{pH} 4.0-10.0$, ionic strength $10-50 \mathrm{mM}$, enzyme loading $1-9 \mathrm{mg} / \mathrm{ml}$, time $1-5 \mathrm{~h}$, temperature $10-50{ }^{\circ} \mathrm{C}$, and adjuvants $(1-30 \% \mathrm{v} / \mathrm{v}$ of methanol, ethanol, 2-propanol, 1-butanol, t-butanol, SDS, ethylene glycol, tween80, and triton X-100). 


\section{Characterization of immobilized lipase}

Lipase activity of immobilized ABL was analysed using $p$-NPP as a substrate over $\mathrm{pH}$ and temperature ranges of $3.0-12.0\left(37^{\circ} \mathrm{C}\right)$ and $20-80^{\circ} \mathrm{C}(\mathrm{pH} 8.0)$, respectively, to identify favourable conditions for lipase reaction. For $\mathrm{pH}$ stability, immobilized $\mathrm{ABL}$ was incubated in $50 \mathrm{mM}$ buffer at the specific $\mathrm{pH}$ for $6 \mathrm{~h}$ at $37{ }^{\circ} \mathrm{C}$ and then the residual activity was determined at $\mathrm{pH}$ 8.0. Buffer systems were acetate ( $\mathrm{pH} 3.0-6.0)$, phosphate (pH 6.0-8.0), Tris- $\mathrm{HCl}(\mathrm{pH} 7.0-9.0)$ and carbonate (pH 10.0-12.0). Thermal stability of immobilized ABL was determined by incubating enzyme at different temperatures for $6 \mathrm{~h}$ in a water bath and then measuring the residual activity using the activity at $60^{\circ} \mathrm{C}$ as control.

Immobilized ABL was mixed with an equal volume of each selected organic solvent to prepare the $50 \%$ organic solution. Mixtures were shaken and incubated at $37^{\circ} \mathrm{C}$ for $12 \mathrm{~h}$ at $150 \mathrm{rpm}$. The solvent contained in the mixture was partially eliminated by evaporation at $37^{\circ} \mathrm{C}$ for $5 \mathrm{~min}$. Residual lipase activity was measured at $37^{\circ} \mathrm{C}$ and $\mathrm{pH} 8.0$ and compared to that of the control (no solvent).

\section{Reusability and storage stability of immobilized lipase}

Immobilized ABL was added to the transesterification reaction described above to determine lipase activity. After $24 \mathrm{~h}$ reaction, the immobilized ABL was collected by filtration, washed 3 times with coldacetone and dried in desiccators at room temperature prior to being added to the next reaction. Each of five reactions was performed for $24 \mathrm{~h}\left(40^{\circ} \mathrm{C}\right)$ and conversion efficiency of each was expressed relative to the original activity. Results were compared with that mediated by commercial lipases (Novozyme 435 and Lipozyme RM IM).

Immobilized ABL (suspended in $20 \mathrm{mM}$ phosphate buffer, $\mathrm{pH} 7.5$ ) was stored at $4{ }^{\circ} \mathrm{C}$ and its stability evaluated from $p$-NPP hydrolytic activity at regular time intervals of 30 days. Hydrolytic activity of fresh purified enzyme was taken to be $100 \%$.

\section{Parameter study for biodiesel production}

Factors affecting biodiesel production catalysed by immobilized ABL were examined under optimum reaction conditions, namely substrate ratio (1:3 to 1:9 mole of palm oil per methanol), amount of catalyst (10-30\% w/w), addition mode of methanol (1-7 steps), water content $(0-5 \%)$, reaction temperature $\left(30-50^{\circ} \mathrm{C}\right)$, and reaction time (3-48 h). Immobilized ABL was used for biodiesel production from palm oil at $250 \mathrm{rpm}, 40^{\circ} \mathrm{C}$ for $24 \mathrm{~h}$. Specificities towards various oil feedstocks were also tested. All experiments were conducted in triplicate, with standard deviations within 5\%. Data were analysed by EXCEL build-in functions.

\section{RESULTS AND DISCUSSION}

\section{Support selection}

Adsorption on hydrophobic supports is an effective, easy and inexpensive method for lipase immobilization $^{22}$. In addition, regeneration is feasible from the reversible adsorption of enzyme on the supports ${ }^{23}$. Most lipases display a large increase in activity when adsorbed on hydrophobic supports, which is ascribed to both conformational micro-tuning and selective adsorption during immobilization ${ }^{23}$. Lipases recognize such supports as natural substrates and undergo interfacial activation during immobilization ${ }^{24}$. In the present study, four commercial inorganic materials were selected as supports based on their properties such as high stability against physical, chemical, and microbial degradation. Highly porous polymer matrices with spherical beads and high hydrophobicity were especially appropriate for application in lipasecatalysed biodiesel production, in terms of greater capacity for enzyme loading and less negative effect from the by-product, glycerol adsorbed on the surface of the enzymes ${ }^{13}$. The physical properties of various supports such as functional groups, specific surface area, pores, and particle sizes have been shown to significantly affect the accessibility and portioning of substrates, products, and water within the reaction mixture ${ }^{13,25,26}$ and consequently the catalytic efficiency of immobilized enzyme. High enzyme loading efficiency $(>89 \%)$ was found for all supports. Immobilized ABL on Sepabeads EC-OD and Amberlite XAD16 showed high hydrolytic activity and that on Sepabeads EC-OD provided the highest transesterification activity (Table 1). This result was consistent with those of $C$. rugosa lipase ${ }^{20}$. When compared with Amberlite XAD16, Sepabeads ECOD has larger pore diameters, increasing enzyme particle adsorption rate ${ }^{27}$. Smaller particles of EC-OD make the external surface of the matrices accessible to enzyme molecules during assay procedures increasing frequency of collisions between substrates and ABL with catalytic activity. In addition, large porous structures facilitate a catalytic expression of immobilized enzyme by reducing limitations on substrate diffusion and product accumulation. Further, improved diffusion enhances biocatalytic reactions by inhibiting substrate or product accumulation inside pores ${ }^{26,27}$. 
Table 1 Activity and efficiency of A. baylyi lipase immobilized on various supports.

\begin{tabular}{lcccc}
\hline Supports & $\begin{array}{c}\text { Hydrolytic activity } \\
\text { of pNPP } \\
\text { (unit/g support) }\end{array}$ & $\begin{array}{c}\text { Hydrolytic activity } \\
\text { of palm oil } \\
\text { (unit/g support) }\end{array}$ & $\begin{array}{c}\text { Transesterification } \\
\text { of palm oil } \\
\text { (\% conversion) }\end{array}$ & $\begin{array}{c}\text { Enzyme loading } \\
\text { efficiency } \\
(\%)\end{array}$ \\
\hline EC-OD & $4.36 \pm 0.02$ & $3.24 \pm 0.21$ & 22.0 & 96.67 \\
XAD7HP & $0.41 \pm 0.07$ & $1.25 \pm 0.11$ & 9.20 & 95.98 \\
XAD16 & $3.92 \pm 0.05$ & $3.83 \pm 0.09$ & 13.24 & 89.07 \\
XAD761 & $0.98 \pm 0.10$ & $1.80 \pm 0.05$ & 13.26 & 92.01 \\
\hline
\end{tabular}

Hence Sepabeads EC-OD were selected as a basal support for the following experiment.

\section{Optimization of immobilization parameters}

Immobilization of ABL on Sepabeads EC-OD between $\mathrm{pH} 4$ and 8 increased lipase activity from $1.60-2.35 \mu \mathrm{mol} / \mathrm{min} / \mathrm{g}$-support but activity decreased at higher $\mathrm{pH}$. It is suggested that low enzyme activity at $\mathrm{pH}$ extremes resulted from either change in enzyme conformation or denaturation. Lipase activity was highest at $\mathrm{pH} 8.0$, close to the isoelectric point of ABL, 7.75 (data not shown) and consistent with its expected maximum adsorption ${ }^{28}$. An increase in lipase activity of immobilized ABL with phosphate buffer ( $\mathrm{pH}$ 8.0) from 1.80-2.45 $\mu \mathrm{mol} / \mathrm{min} / \mathrm{g}$-support correlates with a corresponding increase in ionic strength between 10 and $30 \mathrm{mM}$. High ionic strength however can interfere with enzyme molecules binding to the supports $^{29}$. Hence, beyond an ionic concentration of $30 \mathrm{mM}$, lipase activity of immobilized ABL gradually decreased.

Lipase activity of Sepabeads EC-OD supports loaded with enzyme solution increased (from $1.02-3.98 \mu \mathrm{mol} / \mathrm{min} / \mathrm{g}$-support) with protein concentration from 1-9 $\mathrm{mg} / \mathrm{ml}$, above which it was relatively constant. The lipase activity of immobilized ABL however was steady between 7 and $9 \mathrm{mg} / \mathrm{ml}$ (from 3.85-3.98 $\mu \mathrm{mol} / \mathrm{min} / \mathrm{g}$-support). Possibly this was a result of embedding active sites of lipase molecules during immobilization by increased stacking and diffusion limitations ${ }^{28}$.

Relative residual activity of immobilized ABL optimized for Sepabeads EC-OD reached an equilibrium in $120 \mathrm{~min}$ at $25^{\circ} \mathrm{C}$ after which it remained comparatively unchanged. Time to reach equilibrium varied inversely with temperature and directly with the rate at which lipase activity is reduced. Addition of $10 \%(\mathrm{v} / \mathrm{v})$ methanol as an adjuvant improved lipase activity by approximately $20 \%$ whereas it was reduced by other adjuvants. This is consistent with the suggestion by Fernandez-Lafuente et $\mathrm{al}^{24}$ that short-chain alcohols promote the interfacial activation of lipase

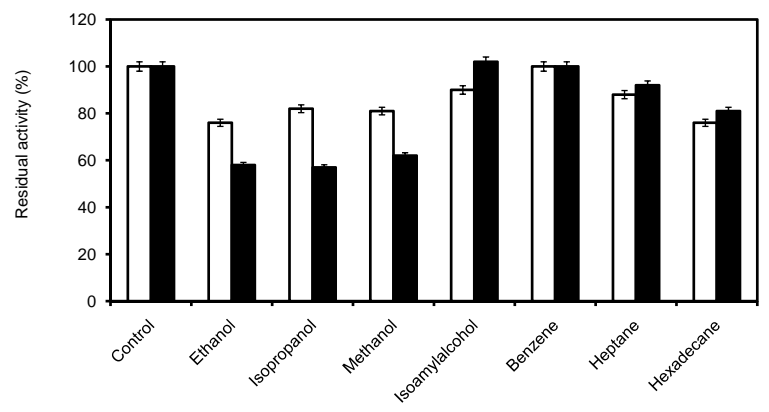

Fig. 1 Effect of organic solvent on suspended (dark solid bars) and immobilized (open bars) A. baylyi lipase. Enzyme was incubated at $37^{\circ} \mathrm{C}$ and shaken at $150 \mathrm{rpm}$ in the presence of $50 \%$ organic solvent for $12 \mathrm{~h}$ and the remaining activity measured in comparison to control (without solvent).

and create an open, substrate-accessible active site.

\section{Stability of immobilized ABL}

Knowledge of optimal conditions and stability of the immobilized enzyme are useful in exploring its potential applications. Both suspended and immobilized ABL exhibited optimal lipolytic activity at $60^{\circ} \mathrm{C}$ with optimum $\mathrm{pH}$ of the former and latter, 8.0 and 9.0, respectively. Immobilized ABL seems more stable in alkaline $\mathrm{pH}(\mathrm{pH} 10.0-12.0)$ than suspended enzyme as half of the activity remained. Our results demonstrate that both suspended and immobilized ABL are stable between 60 and $80^{\circ} \mathrm{C}$. Hydrolytic activity of immobilized ABL enzymes displayed enhanced stability in comparison to that of suspended enzyme in the presence of short-chain alcohols (Fig. 1). Minor conformational changes in enzyme structure after immobilization may take place, increasing stability of the immobilized enzyme ${ }^{30}$.

\section{Reusability and storage stability}

Reuse of immobilized ABL enzyme for transesterification activity was examined since little is used in the chemical process (Fig. 2). Immobilized ABL retained less than $50 \%$ of its initial activity after the 


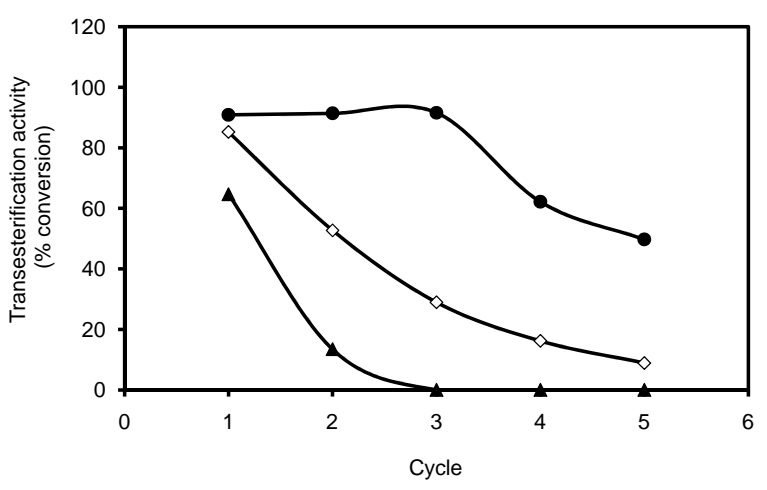

Fig. 2 Reusability of immobilized A. baylyi lipase (open diamonds) Novozyme 435 (closed circles) and Lipozyme RM IM (closed triangles) in subsequent cycles of biodiesel production from palm oil.

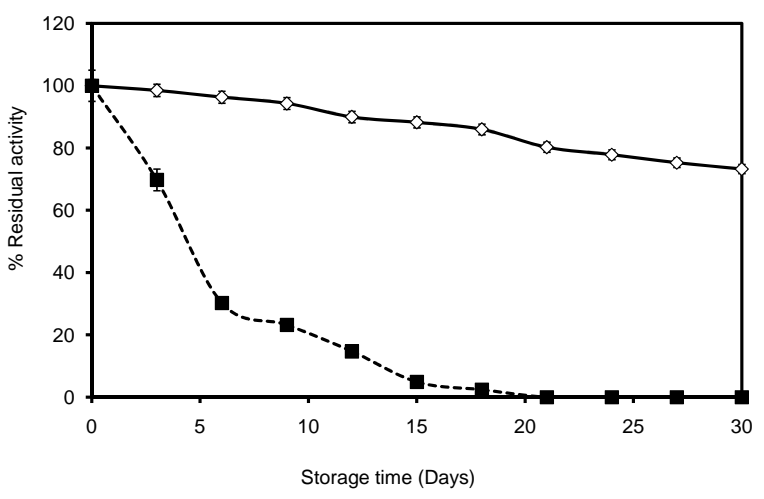

Fig. 3 Storage stability of suspended (closed squares) and immobilized (open diamonds) lipase from A. baylyi.

second cycle of transesterification of palm oil whereas the half-life of Novozyme 435 and Lipozyme RM IM under the same conditions was 5 and 1 cycle, respectively. Activity loss of immobilized ABL in the reaction progress was mainly attributed to leaching of lipase from the supporting surface and conformational changes from repeated use. Because most enzymes are very sensitive to environmental changes, treating them frequently would denature their molecular structure.

Storage stability is one of the most important criteria for the commercial application of an enzyme. Immobilized and suspended ABLs were stored at $4{ }^{\circ} \mathrm{C}$ and activities were measured periodically over 30 days. Immobilized lipase was more stable than suspended enzyme although some leakage from supports occurred for both forms (Fig. 3). Suspended lipase retained only $15 \%$ of its original specific activity after 12 days of storage at $4{ }^{\circ} \mathrm{C}$ while immobilized ABL remained at almost full activity for 30 days. From an economic perspective, the immobilized ABL distinguished itself with acceptable operational and good storage stability appropriate for biodiesel production.

\section{Optimization of the transesterification reaction}

The molar excess of alcohol over fatty acid in oil feedstock often increases the yield of transesterification but it can also inactivate the enzyme. At least three molar equivalents of methanol have been suggested for the complete conversion of oil to fatty acid methyl ester $^{31}$. In this study, the amount of methanol used in the transesterification reaction catalysed by immobilized ABL was varied from 1:3 to 1:9 molar ratio equivalents, based on the mole of palm oil. Optimum methanol concentration was 4 molar ratio of methanol to palm oil at which conversion of methyl esters was about $73 \%$ (Fig. $4 \mathrm{a}$ ). The production was constant with further increases in the methanol concentrations. Methanol was fed into the reaction every $3 \mathrm{~h}$ to reduce its effect on immobilized ABL. Addition of methanol in this manner lead to a 5-fold production over that when all was added at the beginning. Production of biodiesel gradually increased in each additional step and reached a maximum at the sixth step (74\% conversion, Fig. 4b). Slight reductions in conversion efficiency occurred with further additions of methanol. Thus the recommended condition for biodiesel production of palm oil using immobilized ABL catalyst is the 6-step addition of methanol at 1:4 oil/methanol substrate ratios.

Biodiesel production from the transesterification of palm oil with methanol was enhanced with an increasing amount (10-30\% (w/w)) of immobilized ABL. Based on the concentration of palm oil, methanol concentration was tested at 4 molar equivalents. Conversion efficiencies of palm oil to methyl ester differed little between 20 and 30\% enzyme ( 80 and $85 \%$, respectively, Fig. 4c). Thus on the basis of cost saving, the recommended optimum concentration of immobilized ABL is $20 \%$.

Almost all lipases require water for their catalysis either hydrolysis or synthesis ${ }^{32}$. Conversion efficiency from immobilized ABL changed little from $78 \%$ with water increase to $1 \%(\mathrm{v} / \mathrm{v})$ oil but reached a maximum of $92 \%$ at $4 \%(\mathrm{v} / \mathrm{v})$ oil (Fig. $4 \mathrm{~d})$. Water is required for enzyme activation by increasing the available oil-water interfacial area. However, since lipases usually catalyse hydrolysis in aqueous media, excess water may also stimulate competing hydrolytic reactions.

Conversion of palm oil to biodiesel proceeded quickly during the initial $12 \mathrm{~h}$ after which it slowed, 

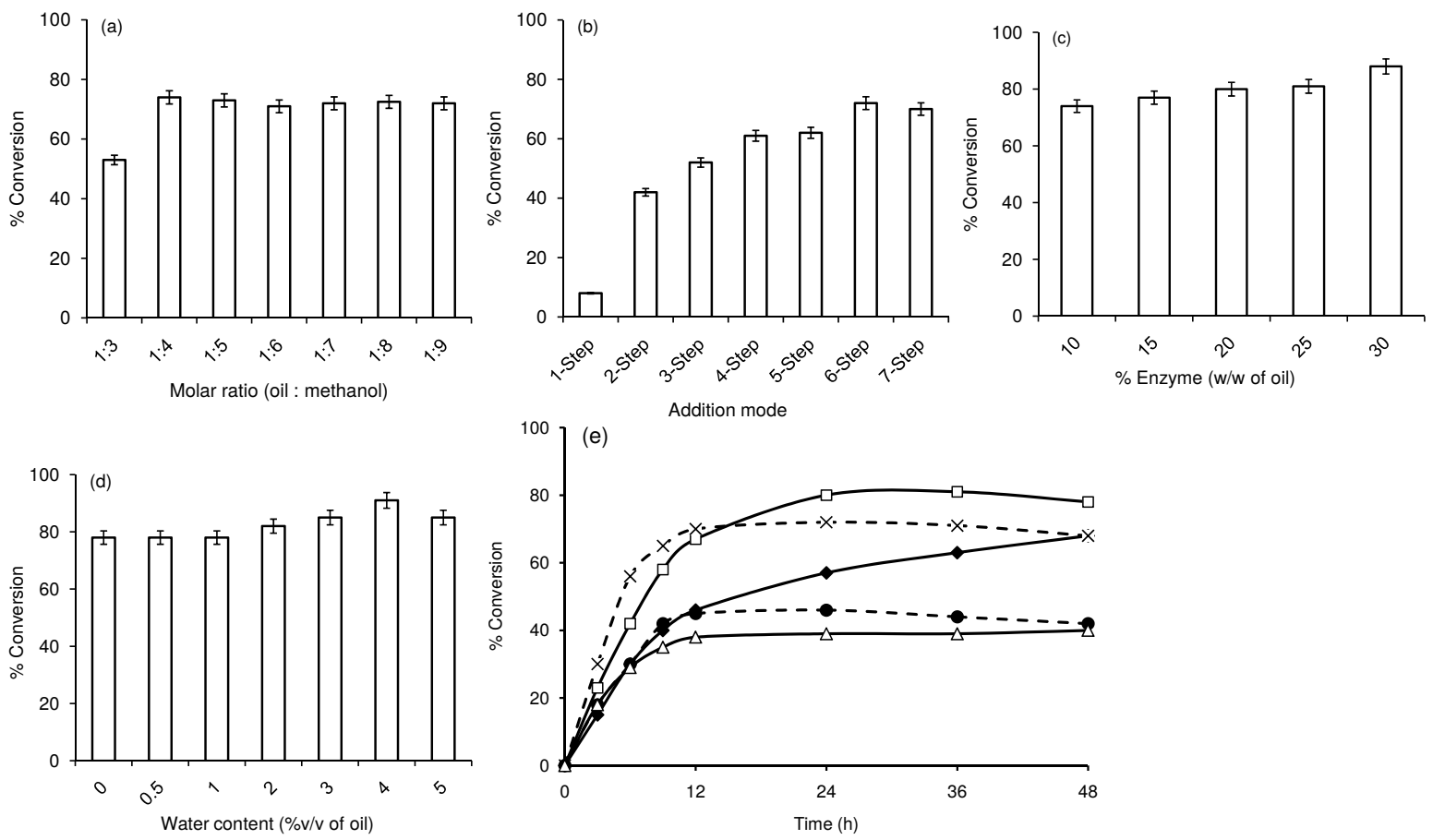

Fig. 4 Effect of (a) methanol concentration, (b) addition mode of methanol, (c) enzyme loading, (d) water concentration, and (e) time course on immobilized A. baylyi lipase catalysed transesterification of palm oil at different temperatures $\left(\triangleleft: 30^{\circ} \mathrm{C}\right.$, $\square: 35^{\circ} \mathrm{C}, \times: 40^{\circ} \mathrm{C}, \bullet: 45^{\circ} \mathrm{C}$, and $\triangle: 50^{\circ} \mathrm{C}$ ).

reaching an equilibrium after $24 \mathrm{~h}$ (Fig. 4e). Transesterification activity of the immobilized $\mathrm{ABL}$ at $40^{\circ} \mathrm{C}$ was optimum, above which it decreased to $50 \%$ at $50{ }^{\circ} \mathrm{C}$. This is attributed to temperature and activation energy being directly related and, the latter, inversely to enzyme inactivation rate. Production of methyl esters was practically identical when incubation time was longer than $24 \mathrm{~h}$.

These results are similar to those reported by Noureddini et al, which were obtained via the methanolysis of soya bean oil using Pseudomonas cepacia lipase immobilized within a sol-gel support ${ }^{33}$. Furthermore, Jegannathan et al documented the complete conversion of palm oil was possible at $30^{\circ} \mathrm{C}$ of reaction temperature with $7: 1$ of methanol to oil molar ratio and $1 \%$ water using Burkholderia cepacia lipase encapsulated in $\mathrm{K}$-carrageenan ${ }^{34}$. But, a higher amount of methanol was required for both reactions.

\section{Production yield of different oil feedstocks}

Edible and non-edible oils were used as substrates for transesterification catalysed by immobilized ABL. Immobilized ABL produced methyl ester from various oils. Biodiesel conversion from palm oil $(93 \pm 2 \%)$ catalysed by immobilized ABL was three times higher than that of suspended lipase ${ }^{9}$. Pro- duction yields $>75 \%$ were found with sesame oil $(77 \pm 5 \%)$, corn oil $(76 \pm 5 \%)$, and physic nut seed oil $(75 \pm 2 \%)$. Conversion efficiencies between $50 \%$ and $70 \%$ were obtained with safflower oil $(68 \pm 4 \%)$, canola oil $(62 \pm 2 \%)$, soya bean oil $(59 \pm 4 \%)$, rubber $(57 \pm 4 \%)$, olive oil $(55 \pm 4 \%)$, papaya seed oil $(55 \pm 3 \%)$, rambutan seed oil $(55 \pm 2 \%)$, and rice bran oil $(55 \pm 2 \%)$. Low yields of biodiesel production (10-40\%) were shown with sunflower oil (39 $\pm 5 \%$ ), pomelo seed oil $(38 \pm 2 \%)$, cotton seed oil $(32 \pm 4 \%)$, pumpkin seed oil $(18 \pm 3 \%)$, and coconut oil $(14 \pm 2 \%)$.

Comparative studies of biodiesel production from palm oil with immobilized ABL and commercial immobilized lipases (Novozyme 435 and Lipozyme RM IM) are summarized in Table 2. Immobilized ABL gave the higher conversion percentage in contrast to lower methanol dosages and reusability frequency. Low reaction temperatures are desirable, as they are closely related to the energy cost inherent to the process of biodiesel production ${ }^{35}$. Immobilized ABL reacted at lower temperatures than those of commercial lipases. This might be interesting. Moreover, high yield of biodiesel produced in the presence of water might be useful for domestic operation because waste cooking oil containing water can be used as biodiesel 
Table 2 Comparison of transesterification from palm oil catalysed by immobilized A. baylyi and commercial lipases.

\begin{tabular}{lccc}
\hline Parameters & \multicolumn{2}{c}{ Immobilized lipase used in the reaction } \\
\cline { 2 - 4 } & Immobilized ABL & Novozyme 435 & Lipozyme RM IM \\
\hline Biodiesel production $(\%$ conversion) & 93 & 72 & 79 \\
Reaction temperature $\left({ }^{\circ} \mathrm{C}\right)$ & 40 & 55 & 55 \\
Reaction time (h) & 24 & 24 & 24 \\
Methanol addition & 6 & 3 & 3 \\
Molar ratio (methanol: palm oil) & $4: 1$ & $3: 1$ & $3: 1$ \\
Enzyme concentration $(\%$ v/v) & 20 & 20 & 20 \\
Water content $(\%$ v/w) & 4 & 0 & 0 \\
Repeated usage (half-life) & 2 & 5 & 1 \\
\hline
\end{tabular}

feedstock $^{36,37}$. However, the data for this study were not based on a commercial application and further examination in recognition of scale could provide helpful information for future large operations.

\section{Conclusions}

Thermophilic-solvent stable lipase from A. baylyi was immobilized on hydrophobic support, Sepabeads EC-OD. Optimal lipase activity and stability occurred at similar $\mathrm{pH}$ and temperature for both suspended and immobilized lipase. Nevertheless, immobilized lipase displayed slightly better stability at alkaline $\mathrm{pH}$ and in the presence of short-chain alcohols and improved storage stability. This immobilized lipase showed comparable efficiency on transesterification with commercial immobilized lipases (Novozyme 435 and Lipozyme RM IM) which could be applied to transesterify and/or hydrolyse a wide variety of oils contained within waste agricultural plant material, resulting in the efficient reuse of these waste products.

Acknowledgements: This work was mainly funded by the National Research Council of Thailand (Grant no. 255355) and partly by the Centre of Excellence on Environmental Health and Toxicology, Science and Technology Postgraduate Education and Research Development Office (PERDO), Ministry of Education, Thailand. We would like to thank F.W.H. Beamish for proofreading the manuscript.

\section{REFERENCES}

1. Demirbas A (2007) Progress and recent trends in biofuels. Progr Energ Combust Sci 33, 1-18.

2. Meher LC, Vidya Sagar D, Naik SN (2006) Technical aspects of biodiesel production by transesterificationa review. Renew Sustain Energ Rev 10, 248-68.

3. Du W, Li W, Sun T, Chen X, Liu DH (2008) Perspectives for biotechnological production of biodiesel and impacts. Appl Microbiol Biotechnol 19, 331-7.

4. Ranganathan SV, Narasimhan SL, Muthukumar K (2007) An overview of enzymatic production of biodiesel. Bioresour Tech 99, 3975-81.
5. Du W, Xu Y, Liu D, Li Z (2005) Study on acyl migration in immobilized lipozyme TL-catalyzed transesterification of soybean oil for biodiesel production. $\mathrm{J} \mathrm{Mol}$ Catal B 37, 68-71.

6. Hsu A, Jones KC, Foglia TA, Marmer WN (2002) Immobilized lipase-catalyzed production of alkyl esters of restaurant grease as biodiesel. Biotechnol Appl Biochem 36, 181-6.

7. Nie K, Xie F, Wang F, Tan T (2006) Lipase catalyzed methanolysis to produce biodiesel: optimization of the biodiesel production. J Mol Catal B 43, 142-7.

8. Shimada Y, Watanabe Y, Samukawa T, Sugihara A, Noda H, Fukuda H, Tominaga Y (1999) Conversion of vegetable oil to biodiesel using immobilized Candida Antarctica lipase. J Am Oil Chem Soc 76, 789-93.

9. Uttatree $\mathrm{S}$, Winayanuwattikun $\mathrm{P}$, Charoenpanich $\mathrm{J}$ (2010) Isolation and characterization of a novel thermophilic-organic solvent stable lipase from Acinetobacter baylyi. Appl Biochem Biotechnol 162, 1362-76.

10. Snellman EA, Colwell RR (2004) Acinetobacter lipases: molecular biology, biochemical properties and biotechnological potential. J Ind Microbiol Biotechnol 31, 391-400.

11. Young DM, Parke D, Ornston LN (2005) Opportunities for genetic investigation afforded by Acinetobacter baylyi, a nutritionally versatile bacterial species that is highly competent for natural transformation. Annu Rev Microbiol 59, 519-51.

12. Bornscheuer UT, Bessler C, Srinivas R, Krishna SH (2002) Optimizing lipase and related enzymes for efficient application. Trends Biotechnol 20, 433-7.

13. Wang L, Du W, Liu D, Li L, Dai N (2006) Lipasecatalyzed biodiesel production from soybean oil deodorizer distillate with adsorbent present in tert-butanol system. J Mol Catal B 43, 29-32.

14. Salis A, Sanjust E, Solinas V, Monduzzi M (2003) Characterization of Accurel MP1004 polypropylene powder and its use as support for lipase immobilization. J Mol Catal B 24-25, 75-82.

15. Winayanuwattikun $P$, Kaewpiboon $C$, Piriyakananon K, Tantong S, Thakernkarnkit W, Chulalaksananukul W, Yongvanich T (2008) Potential plant oil feedstock for lipase-catalyzed biodiesel production in Thailand. 
Biomass Bioenerg 32, 1279-86.

16. Sambrook J, Fritsch EF, Maniatis T (1989) Molecular Cloning. A Laboratory Manual, 2nd edn, Cold Spring Harbor Laboratory Press, Plainview, NY.

17. Uttatree $S$, Charoenpanich J (2011) Nutritional requirements and physical factors affecting the production of organic solvent-stable lipase by Acinetobacter baylyi. CMU J Nat Sci 10, 115-31.

18. Pencreac'h G, Baratii JC (1996) Hydrolysis of $p$ nitrophenyl palmitate in $n$-heptane by the Pseudomonas cepacia lipase: A simple test for the determination of lipase activity in organic media. Enzym Microb Tech 18, 417-22.

19. Yan G, Yang G, Xu L, Yan Y (2007) Gene cloning, overexpression and characterization of a novel organic solvent tolerant and thermostable lipase from Galactomyces geotrichum Y05. J Mol Catal B 49, 28-35.

20. Winayanuwattikun $P$, Kaewpiboon C, Piriyakananon K, Chulalaksananukul W, Yongvanich T, Svasti J (2011) Immobilized lipase from potential lipolytic microbes for catalyzing biodiesel production using palm oil as feedstock. Afr J Biotechnol 10, 1666-73.

21. Bradford MM (1976) A rapid and sensitive method for the quantitation of microgram quantities of protein utilizing the principle of protein-dry binding. Anal Biochem 72, 248-54.

22. Petkar M, Lali A, Caimi P, Daminati M (2006) Immobilization of lipases for non-aqueous synthesis. $J \mathrm{Mol}$ Catal B 39, 83-90.

23. Palomo JM, Mateo C, Fernández-Lorente G, Solares LF, Diaz M, Sánchez VM, Bayod M, Gotor V, Guisan JM, Fernandez-Lafuente R (2003) Resolution of ( \pm )-5substituted-6-(5-choloropyridin-2-yl)-7-oxo-5,6-dihydropyrrolo[3,4b]pyrazine derivatives-precursors of $(S)-(+)$-Zopiclone, catalyzed by immobilized Candida antarctica $B$ lipase in aqueous media. Tetrahedron $\mathbf{1 4}$, 429-38.

24. Fernandez-Lafuente R, Armisén P, Sabuquillo P, Fernández-Lorente G, Guisán JM (1998) Immobilization of lipase by selective adsorption on hydrophobic supports. Chem Phys Lipids 93, 185-97.

25. Lei J, Fan J, Yu C, Zhang L, Jiang S, Tu B, Zhao D (2004) Immobilization of enzymes in mesoporous materials: controlling the entrance to nanospace. Micropor Mesopor Mater 73, 121-8.

26. Palomo JM, Muñoz G, Fernández-Lorente G, Mateo C, Fernández-Lafuente R, Guisán JM (2002) Interfacial adsorption of lipases on very hydrophobic support (octadecyl-Sepabeads): immobilization, hyperactivation and stabilization of the open form of lipases. $J \mathrm{Mol}$ Catal B 19, 279-86.

27. Bosley JA, Clayton JC (1994) Blueprint for a lipase support use of hydrophobic controlled-pore glasses as model systems. Biotechnol Bioeng 43, 934-8.

28. Villeneuve P, Muderhwa JM, Graille J, Haas MJ (2000) Customising lipases for biocatalysis: a survey of chemical, physical and molecular biological approaches.
J Mol Catal B 9, 113-48.

29. Bastida A, Sabuquillo P, Armisen P, Fernández-Lafuente R, Huguet J, Guisán JM (1998) A single step purification, immobilization and hyperactivation of lipases via interfacial adsorption on strongly hydrophobic supports. Biotechnol Bioeng 58, 486-93.

30. Chaubey A, Parshad R, Koul S, Taneja SC, Qazi GN (2006) Arthrobacter sp. lipase immobilization for improvement in stability and enantioselectivity. Appl Microbiol Biotechnol 73, 598-606.

31. Antczak MS, Kubiak A, Antczak T, Bielecki S (2009) Enzymatic biodiesel synthesis-key factors affecting efficiency of the process. Renew Energ 34, 1185-94.

32. Manjón A, Iborra JL, Arocas A (1991) Short-chain flavour ester synthesis by immobilized lipase in organic media. Biotechnol Lett 13, 339-44.

33. Noureddini H, Gao X, Philkana RS (2005) Immobilized Pseudomonas cepacia lipase for biodiesel fuel production from soybean oil. Bioresour Tech 96, 769-77.

34. Jegannathan KR, Jun-Yee L, Chan E-S, Ravindra P (2010) Production of biodiesel from palm oil using liquid core lipase encapsulated in K-carrageenan. Fuel 89, 2272-7.

35. Jeong G-T, et al (2004) Production of biodiesel fuel by transesterification of rapeseed oil. Appl Biochem Biotechnol 114, 747-58.

36. Talebian-Kiakalaieh A, Amin NAS, Mazaheri H (2013) A review on novel processes of biodiesel production from waste cooking oil. Appl Energ 104, 683-710.

37. Atadashi IM, Aroua MK, Aziz ARA, Sulaiman NMN (2012) The effects of water on biodiesel production and refining technologies: A review. Renew Sustain Energ Rev 16, 3456-70. 